\title{
(8)
}

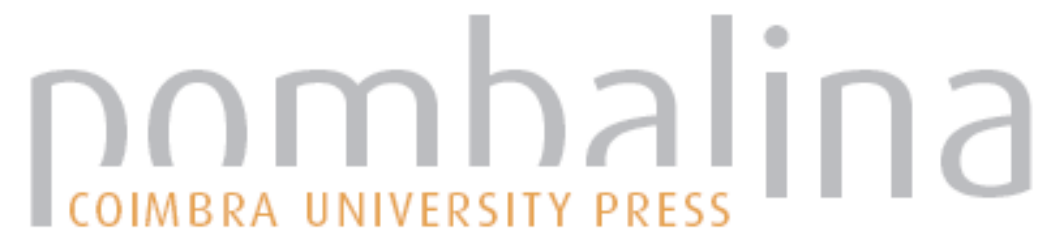

\section{Good practice in collecting samples from human fetus with few gestation weeks}

\author{
Autor(es): $\quad$ Carvalho, M.; Bento, A.; Batista, L.; Oliveira, C.; Sousa, A. P.; Corte- \\ Real, F.; Anjos, M. J.
}
Publicado por: Imprensa da Universidade de Coimbra; International Academy of Legal Medicine

URL
persistente: $\quad$ URI:http://hdl.handle.net/10316.2/31776

DOI: $\quad$ DOI:http://dx.doi.org/10.14195/978-989-26-0173-1_26

Accessed : $\quad$ 26-Apr-2023 14:30:01

A navegação consulta e descarregamento dos títulos inseridos nas Bibliotecas Digitais UC Digitalis, UC Pombalina e UC Impactum, pressupõem a aceitação plena e sem reservas dos Termos e Condições de Uso destas Bibliotecas Digitais, disponíveis em https://digitalis.uc.pt/pt-pt/termos.

Conforme exposto nos referidos Termos e Condições de Uso, o descarregamento de títulos de acesso restrito requer uma licença válida de autorização devendo o utilizador aceder ao(s) documento(s) a partir de um endereço de IP da instituição detentora da supramencionada licença.

Ao utilizador é apenas permitido o descarregamento para uso pessoal, pelo que o emprego do(s) título(s) descarregado(s) para outro fim, designadamente comercial, carece de autorização do respetivo autor ou editor da obra.

Na medida em que todas as obras da UC Digitalis se encontram protegidas pelo Código do Direito de Autor e Direitos Conexos e demais legislação aplicável, toda a cópia, parcial ou total, deste documento, nos casos em que é legalmente admitida, deverá conter ou fazer-se acompanhar por este aviso.

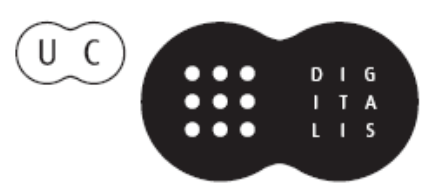




\section{Duarte Nuno Vieira Anthony Busuttil \\ Denis Cusack • Philip Beth}
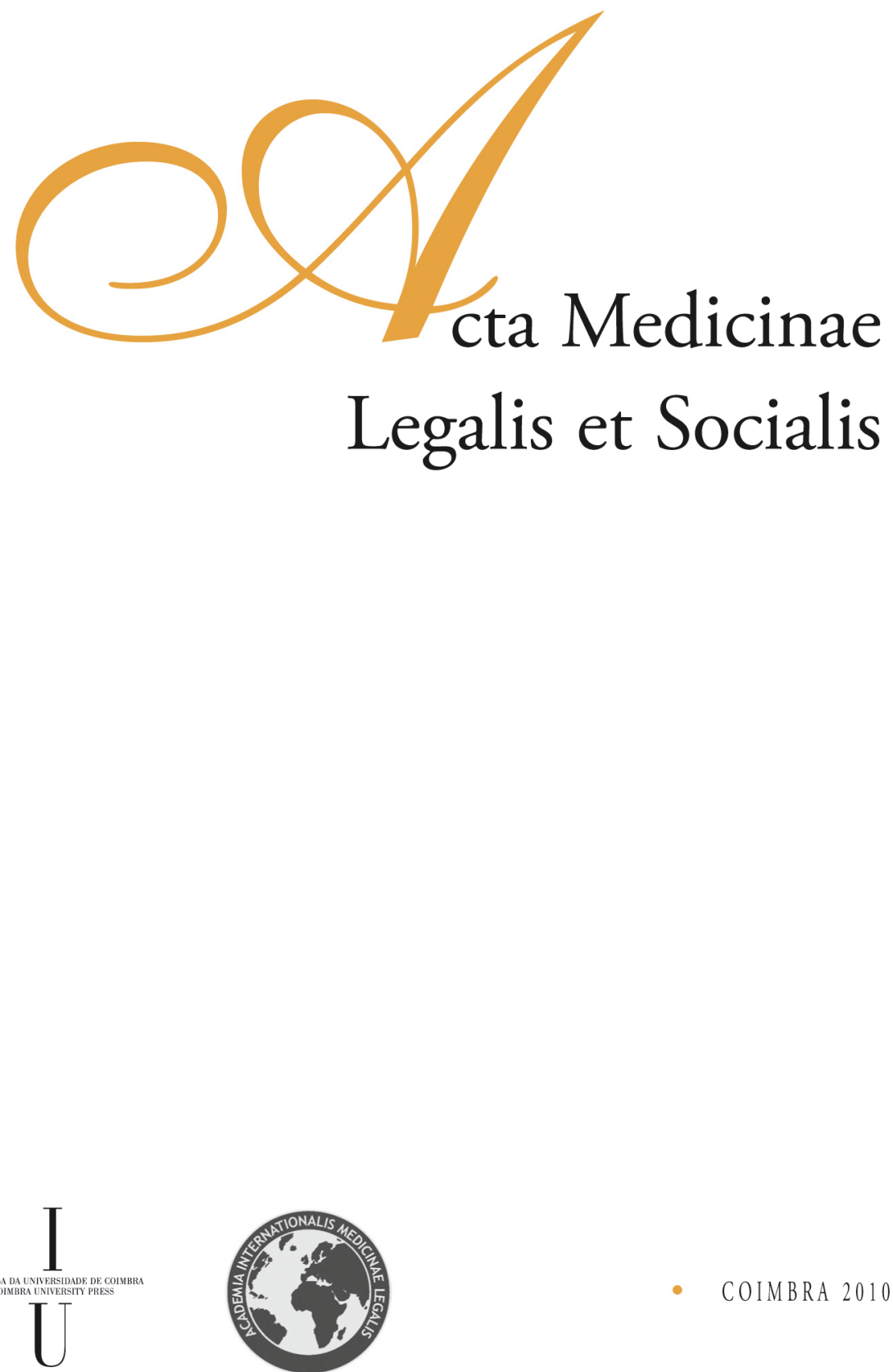
V. Lopes ${ }^{1}$, R. Oliveira ${ }^{2}$, B. Silva ${ }^{3,4}$, A. Serra ${ }^{1}$, F. Balsa ${ }^{1}$, L. Andrade ${ }^{1}$, M. Carvalho ${ }^{1}$, A. Bento $^{1}$, L. Batista ${ }^{1}$, C. Oliveira ${ }^{1}$, A. P. Sousa ${ }^{2}$, F. Corte-Real ${ }^{4,5}$, M. J. Anjos ${ }^{1}$

${ }^{1}$ Genetic and Forensic Biology Department, Centre Branch of the National Institute of Legal Medicine, Portugal

${ }^{2}$ Forensic Clinical Department, Centre Branch of the National Institute of Legal Medicine, Portugal

${ }^{3}$ Forensic Pathology Department, Centre Branch of the National Institute of Legal Medicine, Portugal

${ }^{4}$ Centre Branch of the National Institute of Legal Medicine

${ }^{5}$ Faculty of Medicine, University of Coimbra, Portugal

\title{
GOOD PRACTICE IN COLLECTING SAMPLES FROM HUMAN FETUS WITH FEW GESTATION WEEKS
}

\begin{abstract}
Sometimes when young girls are victim of sexual assault the court determines the interruption of few weeks' gestation pregnancies and the posterior paternity testing to identify the crime perpetrator. In those cases is a good practice to collect samples (blood, skin or oral swabs) by forensic medical experts after the abortion procedure in order to avoid complex and not always successful technical procedures if further are received bones, muscle, paraffin-embedded blocks or, even worst, the whole fetus fixed in formalin.
\end{abstract}

\section{Introduction}

Our Genetic Department performs paternity testing according to court demand. Sometimes when young girls are victim of sexual assault the court determines the interruption of few weeks' gestation pregnancies and the posterior paternity testing to identify the crime perpetrator. If the fetus reference sample is not collected during surgical procedure later we will probably receive bones, muscle, paraffin-embedded blocks or, even worst, the whole fetus fixed in formalin. This will lead to complex and not always successful technical procedures in order to identify their genetic profile. In this context are reported two cases in which legal abortion was made at 15 and 16 gestation weeks. In both cases forensic medical experts were present to perform the collection of reference samples from the mother (blood and saliva) and fetus.

\section{Methodology}

It was performed a rigorous sterile preparation of material and work table. In the operating room, just after abortion procedure, the forensic medical experts made an esternotomy with scalpel. The procedure of incision should be made very carefully since heart must remain intact (figure 1). A $5 \mathrm{cc}$ blood cardiac sample was collected with needle and syringe in order to make a bloodstain (figure 2). In one of the cases were also collected skin tissue (preserved at $-20^{\circ} \mathrm{C}$ ) and an oral swab. 
DNA from blood samples, skin tissue and oral swab was extracted by Chelex method [1] and quantified in an ABI Prism 7000 Sequence Detection System (Applied Biosystems). To identify the fetus genetic profile, the DNA extracted from the three types of samples was amplified by PCR with both commercial kits Identifiler [2] and PowerPlex16 [3]. The detection of PCR products was carried out with an ABI Prism ${ }^{\mathrm{TM}}$ 310 Genetic Analyzer using internal standards (LIZ-500 and I.L.S. 600) and allelic ladders from each kit.

\section{Results}

In all samples were identified complete genetic profiles (17 STRs) that allowed to establishing the fetus paternity. In the case that was also collected an oral swab and skin tissue, the genetic profiles were identical to the one identified in blood.

\section{Conclusions}

Blood, skin and oral swabs leads to very good results and are less time consuming and labour intensive with reduced costs than other kind of sample. In cases of interruption of pregnancy is a good practice to collect samples by forensic medical experts after abortion. The coordination between institutions is essential. Court should inform where and when abortion will occur.

\section{References}

[1] WALSH PS, METZGER DA, HIGUCHI R, Chelex 100 as a medium for simple extraction of DNA for PCR-based typing from forensic material, Biotechniques 10, 4, 506-513, 1991.

[2] AmpFISTR® Identifiler ${ }^{\mathrm{TM}}$. Applied Biosystems.

[3] PowerPlex® 16 System. Promega.

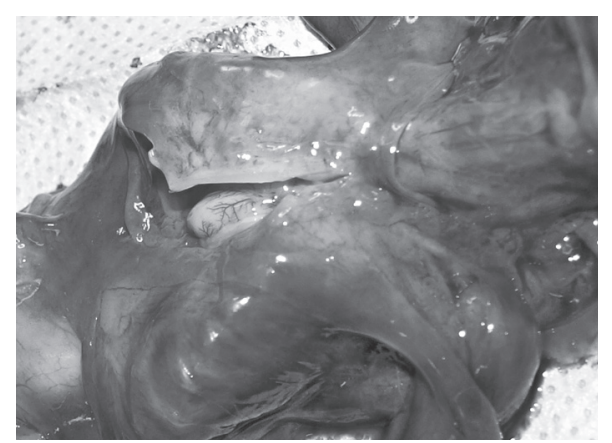

Figure 1 - Heart remains intact after esternotomy with scalpel.

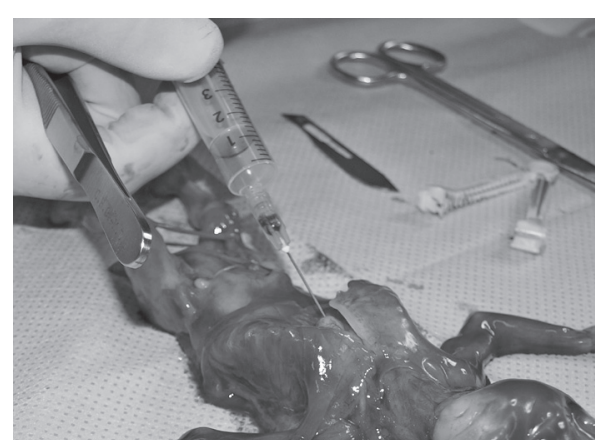

Figure 2 - Collecting a blood cardiac sample. 